\title{
Longitudinal deficiency of upper limb: similar case presentation of two subjects with unilateral ulnar hemimelia, carpal and metacarpal deficiency, and severe oligodactyly
}

\author{
MuhammadAfzal, Sajid Malik \\ Human Genetics Program, Department of Animal Sciences, Quaid-i-Azam University, 45320 \\ Islamabad, Pakistan
}

\begin{abstract}
Background: Longitudinal deficiency of upper limbs with oligodactyly is a very rare congenital malformation. It manifests itself as preaxial or postaxial hypoplasia/aplasia of long bones accompanied by reduction of palm and phalanges.

Objective: To report two cases with essentially similar phenotypic presentation characterized by unilateral mesomelic shortening of limb, ulnar hypoplasia, and severe deficiency of skeletal elements of hand that were found in unrelated individuals.

Methods: Review of clinical and family history, phenotypic examination, physical and radiological investigations, and literature review.

Results: In both individuals, the right arm was short, the size of the middle arm and hand being dramatically reduced in size, and the hand comprising only two functional digits. Roentgenograms revealed hemimelia/ dysmelia of the ulna, hypoplasia of radius, dysplastic distal radial head, and several missing carpals. Only two phalangeal rays were witnessed in the hand. Radiographic measurements showed a normal contralateral arm and lower limbs, and no other associated symptoms. These phenotypes were classified as type I and type D according to the schemes proposed by Swanson et al., and Ogino and Kato, respectively. Both individuals were the product of third degree consanguineous unions $(F=0.0625)$.

Conclusion: Consistent phenotypic pattern of longitudinal limb anomalies evident in two independent subjects suggest a common underlying genetic etiology. There is currently no known genetic factor to allow molecular testing and risk estimation for family members. Isolated limb anomalies may provide important clues to understand pathomorphogenetic mechanisms that lead to the disruption of normal limb development.
\end{abstract}

Keywords: Finger reduction, longitudinal limb deficiency, oligodactyly, Pakistani subjects, ulnar hemimelia

Ulnar hemimelia is a postaxial longitudinal deficiency of the upper limb wherein the ulna is completely or partially absent. The elbow joint may be in extension or in acute flexion [1]. If the deficiency is incomplete, the ulnar remnant may vary in length and contour. The number digits of the hand may be reduced. At the shoulder girdle, one may observe considerable muscular atrophy and ligamentous relaxation [1].

Longitudinal postaxial defects are very rare (prevalence of 8/10,000) [2]. The majority of the cases reported in medical literature are unilateral and

Correspondence to: Dr. Sajid Malik, Human Genetics Program, Department of Animal Sciences, Quaid-i-Azam University, 45320 Islamabad, Pakistan.E-mail: malik@qau.edu.pk sporadic. Similar clinical presentation in several instances may necessitate an underlying genetic nature of these defects. In this clinical report, we present two cases in unrelated individuals depicting remarkably similar phenotypes, i.e., unilateral longitudinal deficiency of right arm, ulnar hemimelia, deficiency of carpal and metacarpal, and severe oligodactyly.

\section{Case studies}

Two unrelated individuals come from Southern Punjab, Pakistan. Both individuals were male and belonged to a Baloch tribe, and were engaged in manual jobs. Family histories were devoid of any hereditary anomaly, and reportedly the pregnancies and birth events had been unremarkable. In both cases, 
there was a parental consanguineous union of third degree relatives being first cousins (with a coefficient of inbreeding in the progeny of $F=0.0625$ ). Detailed socio-demographic, phenotypic and anthropometric data were collected in three visits from June 2009 to September 2010. Photographs and roentgenograms were obtained for clinical evaluation and radiological measurements. This study was approved by our institutional Ethical Review Committee at Quaid-iAzam University, and all information was obtained after written informed consent. The subjects provided written informed consent for publication of their clinical details including photographs.

\section{Case 1}

The subject was 45 years of age and had eight unaffected siblings (5 brothers, 3 sisters) (Table 1 ). He fathered six unaffected offspring (2 sons, 4 daughters). Reportedly, his father dealt in leather processing. The family had a superstitious belief about the occurrence of his limb anomaly.

Upon physical examination, the subject was observed to have two finger remnants of the first and second digits of his right hand, which were short and functional (Figure 1A, C, D). The first digit showed varus deviation, while the other finger had a small nail (Figure 1C). The palm was reduced, typical flexion creases were grossly missing and a feeble transverse crease was evident (Figure 1D).

The radiographs revealed a short, hypoplastic ulna, which did not attain its full size and ended blindly without a proper distal head (Figure 1B, E). The radius was thin and short with a hypoplastic/dysplastic distal head that bent towards the missing end of the ulna. Two dysplastic carpals were visible in the anteroposterior view, while one small floating carpal was observed in the lateral view (Table 2 and Figure 1B). Two metacarpals present were short and stubby. The first digit had two phalanx that showed signs of symphalangism. The second digit harbored three small phalanxes and demonstrated symphalangism at distal interphalangeal joint (DIP). The distal phalanx were hypoplastic in both digits (Figure 1E and Table 2). The left hand was normal with a single transverse palmer crease. In the radiographs, no skeletal element was found missing except crowding of carpals (Figure 1B, E and Table 2).

\section{Case 2}

The subject was 25 years of age. He was initially examined at District Headquarter Hospital, DG Khan (Table 1). The subject had a sibship of two unaffected brothers and three unaffected sisters.

He was observed to have a short right arm with reduced middle and distal segments (Figure 2A, C). The hand was small with a narrow palm harboring two widely spaced digits. Both fingers were short and functional, each bearing two interphalangeal flexion creases and demonstrated varus deviations (Figure 2A, B, C).

Table 1. Sociodemographic and biological attributes of recruited participants

\begin{tabular}{lll}
\hline Variable & Participant 1 & Participant 2 \\
\hline Sex & Male & Male \\
Age (years) & 45 & 25 \\
Origin & Muzaffargarh, Southern Punjab & DG Khan, Southern Punjab \\
Rural/Urban & Rural & Rural \\
Ethnic group & Baloch & Baloch \\
Language & Saraiki & Saraiki \\
Socioeconomic group & Low & Poor \\
Family/household type & Extended & Extended \\
Education/occupation & Primary/manual jobs & Matriculation/manual jobs \\
Marital status & Married & Single \\
Parental consanguinity & First cousin & First cousin \\
Father's age at subject's birth (years) & 23 & 34 \\
Mother's age at subject's birth (years) & 20 & 30 \\
Subject's parity & 7 of 9 & 3 of 6 \\
Normal siblings (brothers:sisters) & $5: 3$ & $2: 3$ \\
Family history of any limb/other genetic defect & No & No \\
Limb anomaly affected & Right arm, unilateral & Right arm, unilateral \\
\hline
\end{tabular}




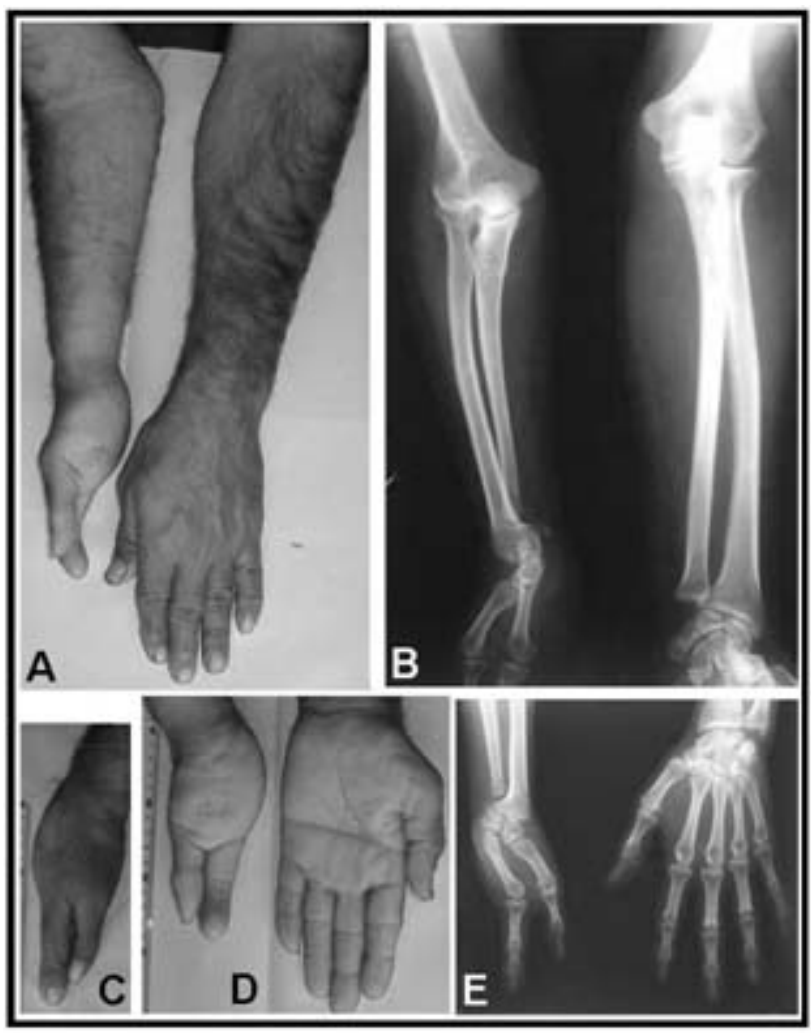

Figure 1. Phenotype in case 1. A-E: Photographs and radiographs of upper limbs, with permission of the subject.

Table 2. General anthropometric and radiological measurements of participants*

\begin{tabular}{|c|c|c|c|c|}
\hline Anthropometric parameters & \multicolumn{2}{|c|}{ Participant 1} & \multicolumn{2}{|c|}{ Participant 2} \\
\hline Standing height & \multicolumn{2}{|c|}{169.0} & \multicolumn{2}{|c|}{165.0} \\
\hline Sitting height & \multicolumn{2}{|c|}{90.0} & \multicolumn{2}{|c|}{82.6} \\
\hline Arm span & \multicolumn{2}{|c|}{166.0} & \multicolumn{2}{|c|}{142} \\
\hline Head circumference & \multicolumn{2}{|c|}{56} & \multicolumn{2}{|c|}{56.0} \\
\hline Neck circumference & \multicolumn{2}{|l|}{37} & \multicolumn{2}{|c|}{38.0} \\
\hline Chest circumference & \multicolumn{2}{|l|}{99} & \multicolumn{2}{|c|}{93.0} \\
\hline Leg length & \multicolumn{2}{|l|}{102} & \multicolumn{2}{|c|}{94.0} \\
\hline Clinical and radiological measurements & Left arm & $\begin{array}{l}\text { Right } \\
\text { arm** }\end{array}$ & Left arm & $\begin{array}{l}\text { Right } \\
\text { arm** }\end{array}$ \\
\hline Movement at shoulder joint & Normal & Normal & Normal & Normal \\
\hline Elbow extension & Normal & Normal & Normal & Restricted \\
\hline Arm length & 75.0 & 61.0 & 70 & 50 \\
\hline Humerus length & - & - & $>31$ & 28.0 \\
\hline Humerus-proximal head circumference & - & - & 6.6 & 5.2 \\
\hline Humerus-distal head circumference & 6.8 & 5.9 & 5.9 & 5.4 \\
\hline Middle arm (zeugopod) & $>28.5$ & $\sim 20$ & $>25$ & $\sim 11$ \\
\hline Radius & 25.5 & 20.2 & 24.6 & 13.2 \\
\hline Radius-distal head & 3.6 & 3 & 3.5 & 2.7 \\
\hline Ulna & 27 & 18 & 24.9 & $7.5 \times 2.8$ \\
\hline Ulna-distal head & 2.3 & 1.1 & 2 & 1.1 \\
\hline Radius/Ulna space & 0.9 & 1.1 & 1.8 & 1.4 \\
\hline Hand (Autopod) & 20.8 & $\sim 14$ & 19.2 & 13.6 \\
\hline Palm & 11.1 & 6.5 & 11 & 6.4 \\
\hline
\end{tabular}


Table 2. (Continue) General anthropometric and radiological measurements of participants*

\begin{tabular}{lllll}
\hline Anthropometric parameters & \multicolumn{2}{c}{ Participant 1 } & \multicolumn{2}{c}{ Participant 2 } \\
\hline Wrist (width) & 7.4 & 5.3 & 6.8 & 5.4 \\
Carpal island 1 & - & $1.9 \times 2.2$ & - & $1.2 \times 0.7$ \\
Carpal island 2 & - & $1.9 \times 1.5$ & - & $1.4 \times 1.0$ \\
Carpal island 3 & - & $0.8 \times 0.9$ & - & $1.7 \times 1.7$ \\
Carpal island 4 & - & - & - & $0.5 \times 0.3$ \\
Carpal island 5 & - & - & - & $0.9 \times 0.6$ \\
Metacarpal I & 4.8 & 4.8 & 4.8 & 4.7 \\
Metacarpal II & 7.6 & 5.9 & 6.9 & 5.2 \\
Metacarpal III & 7.1 & Absent & 6.1 & Absent \\
Metacarpal IV & 6.3 & Absent & 5.4 & Absent \\
Metacarpal V & 5.8 & Absent & 5.0 & Absent \\
Distance b/w I/II metacarpals distal heads & 3 & 1.1 & 2.6 & 2.1 \\
Phalange I & 6.8 & 5.7 & 6.1 & 5.8 \\
Phalange II & 9 & 5.4 & 8.7 & 6.9 \\
Phalange III & 10.2 & Absent & 9.7 & Absent \\
Phalange IV & 9.8 & Absent & 9.2 & Absent \\
Phalange V & 7.5 & Absent & 7.6 & Absent \\
\hline
\end{tabular}

*all measurements are in cm, **affected limb

The radiographs demonstrated a drastically reduced ulna (Table 2). The radius was also short, depicted a varus curvature and was dislocated at the elbow joint (Figure 2D). Five carpals were observed which were crowded and dysplastic. There were only two short metacarpals and two digits. Both digits had hypoplastic distal phalanx. In the upper arm, the humerus appeared weak and thin, its proximal head showed signs of decalcification, while the distal head was atypically thin and malformed (Figure 2D, E). The left arm was unremarkable except clinodactyly of his fifth finger (Figure 2A, B).

\section{Discussion}

We report two independent cases with an essentially similar clinical presentation of a very rare longitudinal limb anomaly. Only a few cases of isolated upper limb deficiencies in the Pakistani subjects have been reported in the medical literature [3-6]. The malformation in both individuals affected right arm only. Both subjects had fully adopted to perform their daily life activities. As a differential diagnosis we considered previously reported well-characterized malformations like femur-fibula-ulna (FFU) complex (OMIM-228200), ulnar hypoplasia with lobster-claw deformity of feet (OMIM-314360), and Schinzel syndrome (OMIM-181450) [7]. However, these anomalous conditions can be safely excluded by virtue of their syndromic nature and the involvement of organ- systems other than the upper limbs (Table 3). Longitudinal upper limb deficiencies are occasionally associated with fusion of the radiohumeral joint, i.e., FFU complex (OMIM). The range of motion, if present, may be markedly limited. The proximal part of the radius may articulate with the underdeveloped capitulum of the humerus, or it may be completely luxated [1]. In the present cases, there was no fusion of radiohumeral joint. First subject has normal movement at the elbow joint while the second subject had restricted extension. Radioulnar fusion was also not witnessed in either subject. Hence on the anatomical basis, the present cases can be classified as type I according to the classification of Swanson et al. [8] (i.e., hypoplasia or partial absence of ulna), and as type D according to the scheme proposed by Ogino and Kato [9] (i.e., absent ulnar three fingers) (reviewed in Al-Qattan et al. [10]).

Longitudinal limb defects resulting in deficiency of forearm and/or fingers have a profound impact on the physical, psychological, and vocational life of the affected individual. The etiology of these defects is poorly understood. The majority of the postaxial longitudinal limb anomalies reported continuously in the thalidomide and post-thalidomide periods, are sporadic, unilateral, isolated and nonsyndromic, which may lead to infer a nongenetic etiology. However, there have been consistent phenotypic patterns in many independent cases, and frequent observations as a part 
of several well-characterized syndromes (i.e., Schinzel syndrome, OMIM-181450; postaxial acrofacial dysostosis, OMIM-263750; Weyers syndrome, OMIM-602418; FFU syndrome, OMIM-228200; Brachmann-de Lange syndrome, OMIM-122470; ulnar hypoplasia with lobster-claw deformity of the feet, OMIM-314360; tetramelic postaxial oligodactyly, OMIM-176240), and reports of familial transmissions $[2,7,10]$. They do suggest a common underlying genetic factor(s) in a substantial number of instances. However, currently there are no molecular diagnostic tests that could help prove that these individuals with similar clinical manifestations have the same genetic etiology.

Congenital limb defects in humans provide valuable cues to understand limb developmental plans [11]. Longitudinal limb anomalies highlight the disruption of normal morphogenetic programs operating particularly along the anteroposterior and proximodistal axis of the limb bud, which maintain the digit number and identity, and the length of the growing bud, respectively [11]. The number of digits that form is contingent upon the number of cells available in the growing limb field, the width of the bud and the length of the apical ectodermal ridge (AER) [11, 12]. The most important player in anteroposterior developmental axis is Sonic hedgehog (Shh), complete loss of which has been shown to cause loss of postaxial fingers in animal models. For instance, Chiang et al. [13] and Ros et al. [14] have shown that the complete inactivation of Shh in the mouse and chick result in the loss of all digits in forelimbs. Recent studies have reaffirmed that the posterior digits are lost when Shh signaling is inhibited, which causes a combination of reduced anteroposterior growth and specification [11, 15]. In conclusion, failure to maintain the cell number or a localized loss of part of AER (via fibroblast growth factor signaling), or partial loss of function of the Shh pathway, may be a plausible mechanisms leading to longitudinal limb defects. Molecular studies on large number of subjects with a rather uniform phenotypic presentation, and cases with familial Mendelian patterns would be valuable in elucidating the genetic factors that disrupt normal patterning and produce these defects.

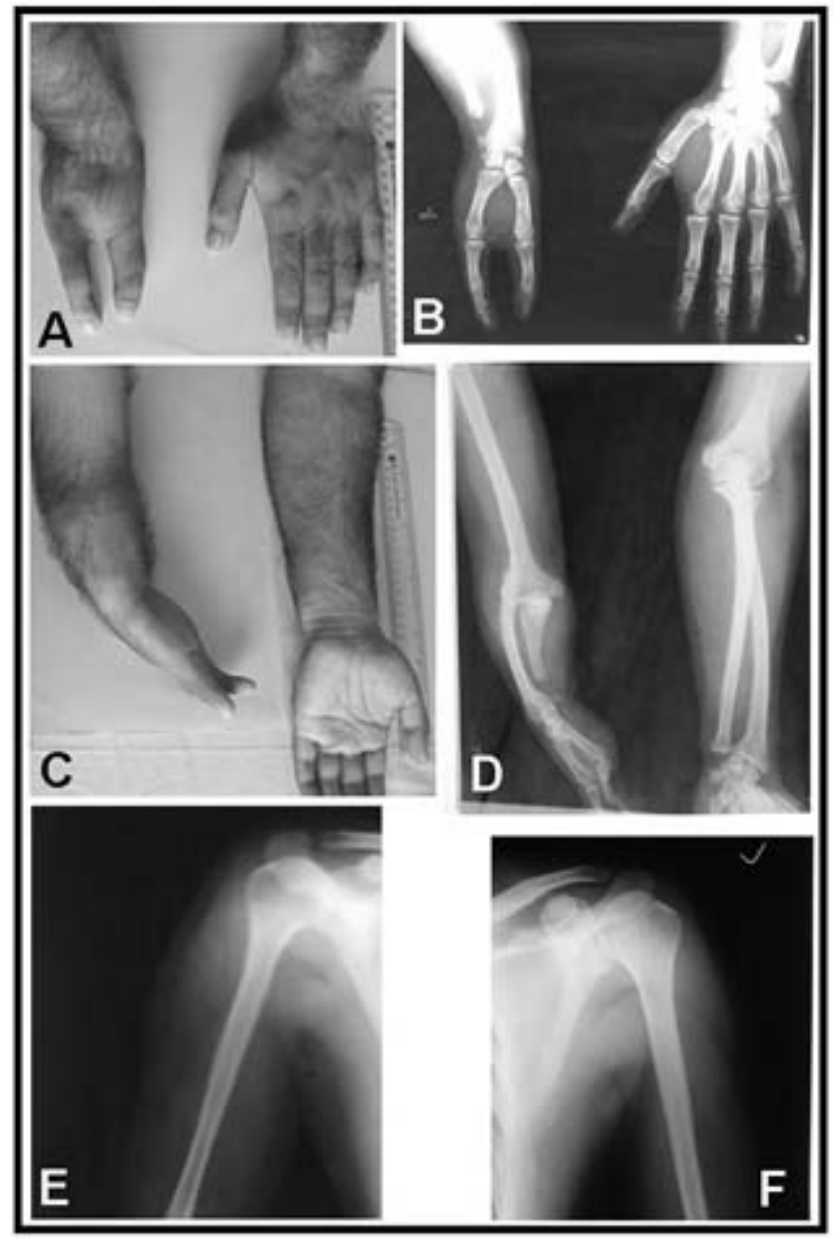

Figure 2. Phenotype in subject 2. A-E: Photographs and radiographs of upper limbs, with permission of the subject. 
Table 3. Differential diagnosis: upper limb malformations with ulnar deficiency/postaxial oligodactyly

\begin{tabular}{|c|c|c|c|c|}
\hline $\begin{array}{l}\text { Malformation - } \\
\text { OMIM }\end{array}$ & $\begin{array}{l}\text { Inheritance; locus; } \\
\text { gene }\end{array}$ & Upper limb & Lower limb & Associated defects \\
\hline $\begin{array}{l}\text { Weyers oligodactyly } \\
\text { syndrome; } 602418\end{array}$ & Autosomal dominant & $\begin{array}{l}\text { Ulnar or radial reduction, single } \\
\text { central incisor, and renal, splenic, } \\
\text { or cardiac anomalies }\end{array}$ & Fibular reduction & $\begin{array}{l}\text { Single central incisor, } \\
\text { hypotelorism, } \\
\text { splenic, cardiac, } \\
\text { splenic and renal } \\
\text { anomalies }\end{array}$ \\
\hline $\begin{array}{l}\text { Femur-fibula-ulna } \\
\text { complex, FFU } \\
\text { syndrome; } 228200\end{array}$ & Usually sporadic & $\begin{array}{l}\text { Defects of ulna/ulnar rays; } \\
\text { amelia/peromelia at lower end of } \\
\text { humerus, humeroradial synostosis }\end{array}$ & $\begin{array}{l}\text { Proximal focal } \\
\text { femoral deficiency }\end{array}$ & \\
\hline $\begin{array}{l}\text { Miller syndrome; } \\
263750\end{array}$ & $\begin{array}{l}\text { Autosomal recessive; } \\
\text { 16q22; DHODH }\end{array}$ & $\begin{array}{l}\text { Hypoplasia/aplasia of postaxial } \\
\text { elements }\end{array}$ & $\begin{array}{l}\text { Hypoplasia/aplasia } \\
\text { of postaxial }\end{array}$ & $\begin{array}{l}\text { Coloboma of eyelids, } \\
\text { pinna defects, } \\
\text { supernumerary } \\
\text { nipples, severe } \\
\text { micrognathia, cleft } \\
\text { lip/palate }\end{array}$ \\
\hline $\begin{array}{l}\text { Ulnar hypoplasia with } \\
\text { lobster-claw deformity } \\
\text { of feet; } 314360\end{array}$ & $\begin{array}{l}\text { X-linked recessive or } \\
\text { autosomal dominant } \\
\text { sex-influenced }\end{array}$ & Absence of ulna and 2-5 fingers & $\begin{array}{l}\text { Lobster-claw } \\
\text { deformity }\end{array}$ & \\
\hline $\begin{array}{l}\text { Tetramelic postaxial } \\
\text { oligodactyly; } 176240\end{array}$ & Autosomal dominant & $\begin{array}{l}\text { Bowing of radii, absence of 5th } \\
\text { metacarpal and phalange }\end{array}$ & $\begin{array}{l}\text { Absence of 5th } \\
\text { metatarsal and } \\
\text { phalange }\end{array}$ & \\
\hline $\begin{array}{l}\text { Cornelia de Lange } \\
\text { Syndrome; } 122470\end{array}$ & $\begin{array}{l}\text { Autosomal dominant; } \\
\text { 5p13.1; NIPBL }\end{array}$ & $\begin{array}{l}\text { Ulna hemimelia, } \\
\text { oligodactyly/monodactyly }\end{array}$ & & $\begin{array}{l}\text { Facial dysmorphism, } \\
\text { low anterior hairline, } \\
\text { synophrys, } \\
\text { anteverted nares, } \\
\text { growth retardation }\end{array}$ \\
\hline $\begin{array}{l}\text { Ulnar/fibular ray } \\
\text { defect and } \\
\text { brachydactyly; } \\
608571\end{array}$ & Autosomal dominant & $\begin{array}{l}\text { Ulnar hypoplasia, brachydactyly, } \\
\text { ulnar ray defects, missing fourth } \\
\text { and fifth fingers }\end{array}$ & $\begin{array}{l}\text { Fibular } \\
\text { hypoplasia, } \\
\text { clubfeet }\end{array}$ & $\begin{array}{l}\text { Short stature; growth } \\
\text { retardation, } \\
\text { hypoplastic midface, } \\
\text { atrial septal defect, } \\
\text { hemangiomas }\end{array}$ \\
\hline $\begin{array}{l}\text { Al-Awadi/Raas- } \\
\text { Rothschild syndrome; } \\
276820\end{array}$ & $\begin{array}{l}\text { Autosomal recessive; } \\
\text { 3p25.1; WNT7A }\end{array}$ & Absent ulna & $\begin{array}{l}\text { Absent fibula, } \\
\text { hypoplastic } \\
\text { femora, pelvic } \\
\text { deformity, } \\
\text { oligodactyly }\end{array}$ & $\begin{array}{l}\text { Skull defects, } \\
\text { thoracic dystrophy, } \\
\text { diaphragmatic hernia, } \\
\text { urogenital problems }\end{array}$ \\
\hline $\begin{array}{l}\text { Schinzel syndrome; } \\
181450\end{array}$ & $\begin{array}{l}\text { Autosomal dominant; } \\
12 \mathrm{q} 24.1 ; T B X 3\end{array}$ & $\begin{array}{l}\text { Hypoplasia of ulna/radius and } 5^{\text {th }} \\
\text { terminal phalange, postaxial } \\
\text { polydactyly }\end{array}$ & Normal & $\begin{array}{l}\text { Hypoplasia of breasts } \\
\text { and apocrine glands, } \\
\text { obesity, delayed } \\
\text { development, } \\
\text { abnormality of teeth, } \\
\text { palate, vertebral } \\
\text { column and } \\
\text { urogenital system }\end{array}$ \\
\hline
\end{tabular}

\section{Acknowledgements}

We acknowledge the participation of the subjects in this study, help of doctors at District Headquarter Hospitals, and the useful comments of Prof. Dr. Mahmud Ahmad. This work was supported by research grants from HEC-Pakistan and PSFPakistan. We have no conflict of interest to report in this study.

\section{References}

1. Frantz CH, O’Rahilly R. Ulnar hemimelia. Artificial Limbs. 1971; 15:25-35.

2. McGuirk CK, Westgate MN, Holmes LB. Limb deficiencies in newborn infants. Pediatrics. 2001; 108: E64.

3. Malik S, Jabeen N. Zygodactyly with thumb aplasia: an unusual variant in a male subject. J Col Phy Surg Pak. 2011; 21:710-2. 
4. Riaz HF, Malik S. Case report of a neonate with congenital transverse deficiency of hand. Pak J Med Sci. 2011; 27:1177-80.

5. Malik S, Afzal M. Ulnar aplasia, dysplastic radius and preaxial oligodactyly: rare longitudinal limb defect in a sporadic male child. J Res Med Sci. 2013; 18:818-21.

6. Riaz HF, Lal K, Ahmad B, Shuaib M, Naqvi SF, Malik S. Study of non-syndromic thumb aplasia in six independent cases. Pak J Med Sci. 2014; 30:677-81.

7. OMIM. Online mendelian inheritance in man. [online]. 2014. [cited 2014 Jun 15]; Available from: http://www. ncbi.nlm.nih.gov/omim

8. Swanson AB, Tada K, Yonenobu K. Ulnar ray deficiency: its various manifestations. J Hand Surg [Am]. 1984; 9:658-64.

9. Ogino T, Kato H. Clinical and experimental studies on ulnar ray deficiency. Handchir Mikrochir Plast Chir. 1988; 20:330-7.

10. Al-Qattan MM, Al-Sahabi A, Al-Arfaj N. Ulnar ray deficiency: a review of the classification systems, the clinical features in 72 cases, and related developmental biology. J Hand Surg [E]. 2010; 35: 699-707.

11. Grzeschik K-H. Human limb malformations; an approach to the molecular basis of development. Int J Dev Biol. 2002; 46:983-91.

12. Towers M, Tickle C. Growing models of vertebrate limb development. Development. 2009; 136:179-90.

13. Chiang C, Litingtung Y, Lee E, Young KE, Corden JL, Westphal H, Beachy PA. Cyclopia and defective axial patterning in mice lacking Sonic hedgehog gene function. Nature. 1996; 383:407-13.

14. Ros MA, Dahn RD, Fernandez-Teran M, Rashka K, Caruccio NC, Hasso SM, et al. The chick oligozeugodactyly (ozd) mutant lacks sonic hedgehog function in the limb. Development. 2003; 130:527-37.

15. Scherz PJ, McGlinn E, Nissim S. Tabin CJ. Extended exposure to Sonic hedgehog is required for patterning the posterior digits of the vertebrate limb. Dev Biol. 2007; 308:343-54. 